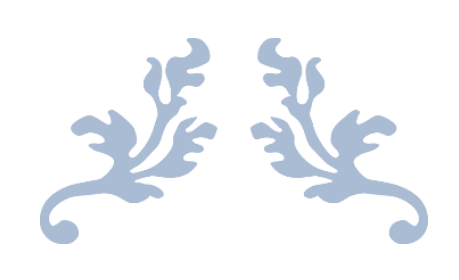

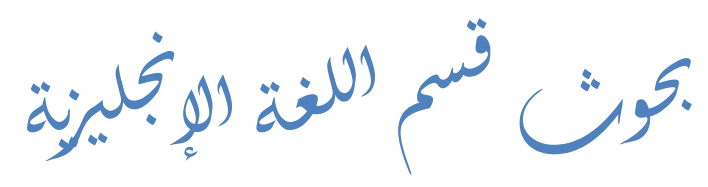




\title{
Fear in $\mathrm{V}$ for vendetta
}

Noha Alhussein Mostafa

PHD student

\begin{abstract}
الملخص :تسعى الورقة إلى دراسة الخوف في الفاء تشير إلى فانديتا ، وتتتبع بعض تقنيات

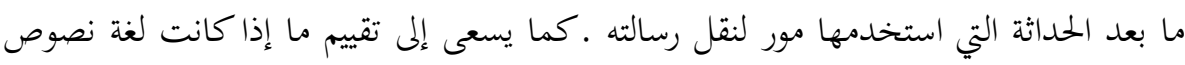

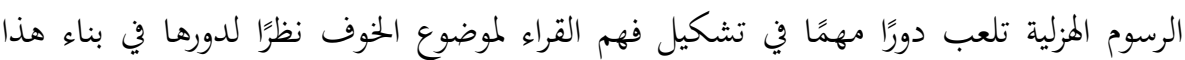

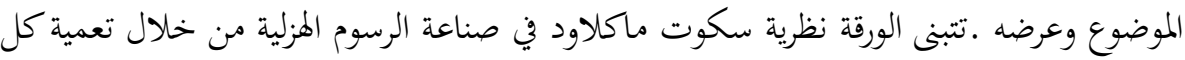
من الكلمات والصور اعتمادًا على خمسة خيارات: اختيار اللحظة ، واختيار الإطار ، واختيار

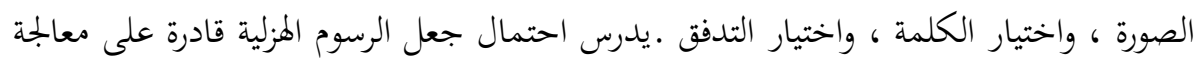
موضوع الخوف من خلال الكلمات والصور بأكثر الطرق فعالية من الناحية الجمالية.
\end{abstract}

\section{Abstract:}

The paper seeks to study the literary essence of $\mathrm{V}$ for Vendetta, and traces some of the postmodern techniques that Moore has used to convey his message. It also seeks to assess whether the image-text language of comics plays an important role in shaping the readers' understanding of the theme of fear due to its role in constructing and displaying this theme. The paper adopts Scott McCloud's theory of making comics by blinding both word and images depending on five choices: choice of moment, choice of frame, choice of image, choice of word, and choice of flow. It examines the probability of making comics capable of tackling the theme of fear through both words and images in the most aesthetic effective way. 
This paper considers $V$ for Vendetta as an outstanding postmodern piece of work that has paved the way for comics to be regarded as a sophisticated literary genre. Generally, postmodernism refers to certain features of post- World War II literature. It opens the doors for a completely new manner of thinking, of perceiving things. It can be thought of as a movement that emphasizes that out of the many types of the traditional literary genre, comics stands out as particularly a postmodern genre in terms of themes and techniques. $V$ for Vendetta, through its words and images, celebrates many postmodern techniques, including but not restricted to hybridity, deconstruction, irony, intertextuality, historiographic metafiction, nonlinear narratives, different and unreliable narrators, and a tendency towards scattering chaos in opening and closure.

The main argument is that comics collaborates between words and images to provide a unique reading experience and provide depth to the meaning. McCloud's book, Making Comics: Storytelling Secrets of Comics, Manga and Graphic Novels, should be considered a reference in analyzing comics. It explains how plots are narrated, how characters and setting are portrayed, and how themes are delivered with the right amount of details using five choices: choice of moment, choice of frame, choice of image, choice of word, and choice of flow. Compiling these five choices in comics showcases how readers could get the best out of their reading experience. McCloud states, 
"Together these five choices are what communication through comics requires." (37) McCloud's choices are mostly focused on establishing rich, clear themes by integrating words and images to convey an outstanding reading experience that traditional narrative might never be able to deliver to its readers.

Thus, one can argue that, "the winding, bumpy road of comics, travelled for so long, has finally turned into something closer to a smooth superhighway" thanks to the contributions of Scott McCloud (Lent 27) He is one of the pioneers who aims at studying and discovering comics. Hatfield claims, "Comics Studies has been an ad-hoc phenomenon, a field generated not by institutional/ mandate but by the eager scurrying of independent actors, opportunistically seeking niches here and there in which they can study this neglected art form and its culture." ("Foreword, Comics Studies: The Anti-discipline" IV) Yet, McCloud initiates the field of studying and theorizing comics. Thanks to his books, "Comics were reinvented as a more sophisticated medium." (Lent 7) That is to say, McCloud's efforts "have had a strong impact on artistic practice and academic research". (Hatfield, Alternative comics: An Emerging Literature 11) McCloud's works are widely celebrated in academic circles. Many have praised McClould to the extent of deeming him as the founding father of the field of Comics Studying. It is suggested, "Scott McCloud is the Aristotle of Comics, showing the way for contemporary thinkers who would seek to rigorously 
analyze emerging media. What Aristotle did for Attic drama in the Poetics, McCloud has done for the neglected form of comics". (Wardrip-Fruin \& Montfort 710)

$V$ for Vendetta is examined through Scott McCloud's theory regarding the use of both words and images in comics to create a medium capable of handling outstanding thoughtful themes. Wolk suggests, "Comics simultaneously feed the parts of the brain that make sense of written language and pictures." (23) If literature requires significance in the theme of a text, then perhaps comics could fit in the description of literature. If comics is capable of depicting a rich tapestry of themes, as comics resembles "a testing ground for ideas that might or might not make it to other media", then, $V$ for Vendetta can be consider of the pioneer masterpieces that have accentuated this notion. (Wandtke 193) Comics handles wide range of themes and ideas, as it can "engage with the horizon of history", "portray torture and massacre", "envision an everyday reality of women's lives", and "sexual difference". (Chute 458) In addition, as Meskin notes, "That is, readers are not simply confronted with clichés - they are encouraged to work out themes, contemplate them, and make sense of the comics in light of them." (221) The fact that comics leave place for contemplation and mental practice for the reader to attempt to decode the themes is an indication that they should be deemed as literature. One of these themes is fear; as $V$ for Vendetta stands for expressing the inevitable consequences of the repressive tendencies associated with some of the practices of the government of the United 
Kingdom. It anticipates how abusive government can use fear to keep people under repression. Thus, the paper focuses on the possibility of having an extraordinary ability in tackling the theme of fear in this comics in a more attractive way than other established literary genres using both words and images through five choices: choice of moment, choice of frame, choice of image, choice of word, and choice of flow.

Since the very beginning, Fear spreads in the atmosphere through both words and images. This postmodern word-image hybrid script successfully narrates the story, reflects the theme of fear and creates literature. Visually, it opens on the 5th of November, 1997, which at the time of publication was not a too-distant future. Panels cut between different gloomy settings; surveilled London at night, Evey's room while she is getting dressed to go out with a look of fear and concern and V's place where V is putting on his gloves, mask, wig and black cloak. Meanwhile, verbally, the Voice of Fate is broadcasting about weather, quarantine zones, meat rationing, a terrorist ring, the sixteen-year-old Queen Zara's activities, and the brighter industrial prospects. Thus, it is analyzed, "The British government is staging a nonexistent, deceitful prosperity, and $\mathrm{V}$ thus prepares his disguise, because he, too, will start off a spectacular performance." (Di Liddo 114) 
Evey goes out to work as a prostitute to fund her financial problems. Unfortunately, she bumps into men who happen to be fingermen. Despite the fact that the fingermen's responsibility obliges them to stop her from prostitution and take her into custody, they decide to abuse their authority and make full use of Evey's acquired fear of Norsefire's totalitarian government and its members. They decide to rape and kill her. All that Evey can do is fear. She does not stand for herself, she only begs for her life. Meanwhile, V appears and runs the men through while quoting Shakespeare's Macbeth. V defends Evey and attacks fingermen using martial arts, then carry Evey to safety.
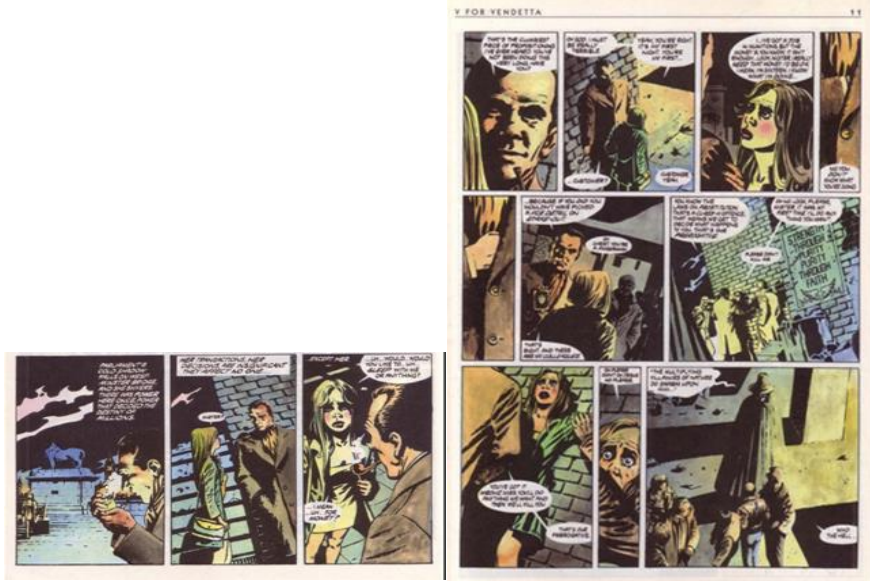


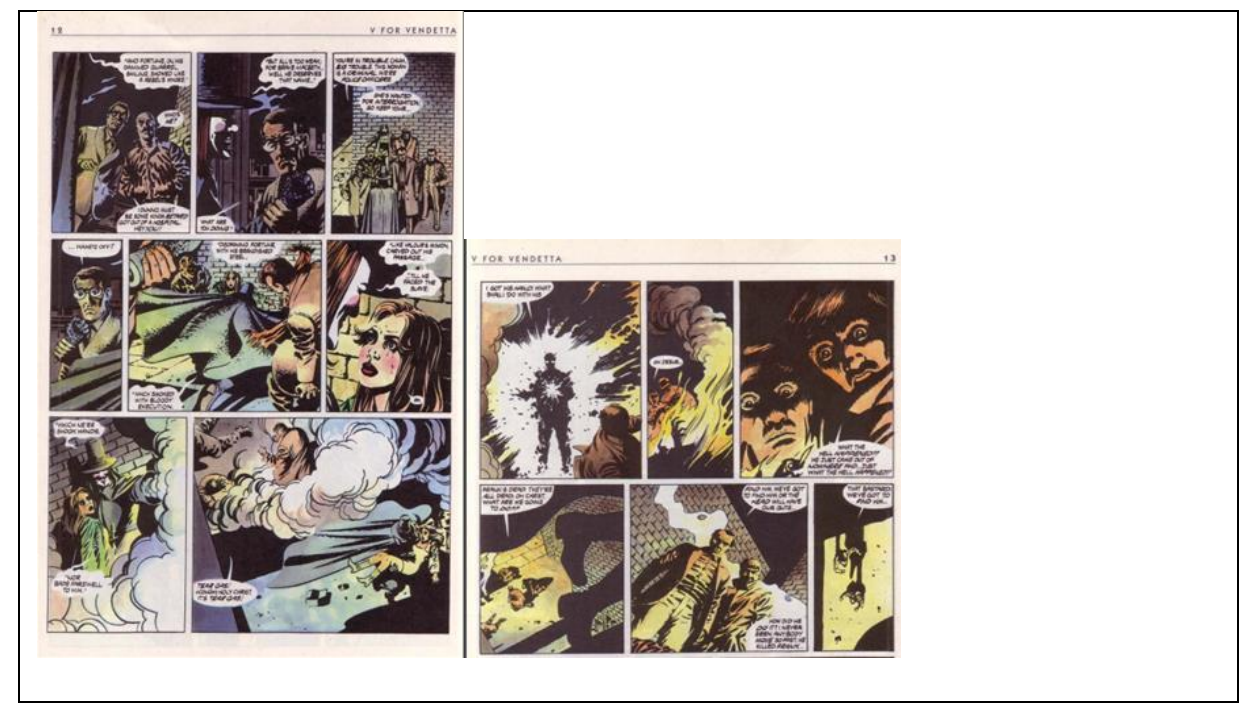

(Fig. (1) - Moore 10-13)

Here, the choice of moment is perfect; it shows what matters and directs the reader where to focus as fear prevails the scene. In transitioning from one panel to another, subject-to-subject transition is utilized, while changing angles of view to direct reader's attention to Evey's terrible fear of the fingermen. It is suggested, "This is where the power of subject-to-subject transitions lies: the ability to facilitate thought and imagination through reader participation." (McCafferty, Art Ducko) Thus, this transition accentuates Evey's fear; Evey does not resist of fight her attackers, she is grabbed by fear.

Regarding the choice of frame, it guides the readers to notice how bad Evey's fear is. Concerning Camera angle, Low Angle is utilized in the panel showing the attack scene to reflect the powerlessness of Evey. The background of a low angle shot lacks detail about the setting to inspire fear 
and insecurity. Concerning Distance, it is close or even too close to show all the appropriate details of Evey's facial expression that reflects her deep fear. Yet, when needed, it becomes slight far to let the reader know where the action is taking place and give a sense of the gloomy atmosphere. Readers find themselves can not get away from reading the poster hanged on the wall, "STRENGTH THROUGH PURITY, PURITY THROUGH FAITH". (Moore 11) This slogan is used by Norsefire government as propaganda to get the people to believe that they will only be strong if there is pure unquestioning trust in the government. Concerning centering: it is established that readers assign importance to characters and objects placed in the center. That is why Evey's fear as well as fingermen's violence are placed in the center.

The choice of image helps in bringing the fear from Norsefire's totalitarian government to life visually. The precise designing both Evey's and fingermen's characterization as well as the gloomy constructing of the setting where they exist within is amazing. Evey is drawn as an unexperienced terrified petite girl who lacks selfconfidence, whereas the characters of fingermen are drawn as huge men who lack sympathy and possess physical strength and unlimited authority. Concerning facial expressions, Evey's fear, and sadness are drawn as obvious as fingermen's disgust and aggression. Regarding body language, both Evey's and fingermen's body poses and physical actions convey a political message. Portraying the low humble Evey versus the high powerful fingermen, and 
showing the way they use their hands to paralyze her to attack her reflect a more deliberate message concerning the attitudes of Norsefire government. This scene emphasizes the fear relation between Norsefire's totalitarian government and the suppressed citizens of England.

Regarding the choice of word, in the panels displaying Evey while being attacked, an intersecting form of communication where words and pictures work together in some respects while also contributing information independently is utilized. They stress on the theme of fear and expose it to the readers to achieve better compassion and sympathy. Evey says, "Oh no. Look, please, mister. It was my first time. I'll do anything you want. Please don't kill me." And a fingerman replies, "You've got it wrong Miss. You'll do anything we want and then we'll kill you. That's our prerogative." (Moore 12) Moreover, while rescuing Evey, a postmodern technique is utilized, which is intertextuality, as V's words are quotes from Shakespeare's Macbeth. Following both words and images, readers find themselves resembling $V$ ' heroic rescuing of Evey to the heroic deeds of Macbeth.

It is declared, "The most direct message of the words V pronounces while carrying out Evey's rescue is to make his heroic stature clear: heedless of danger like Macbeth, he attacks the villains and saves the girl." (Di Liddo 37) To make it clear to readers that Evey is almost a slave to her fear, $\mathrm{V}$ quotes: 
The multiplying villainies of nature do swarm upon him...And fortune, on his damned quarrel smiling, showed like a rebel's whore. But all's too weak; For brave Macbeth, - well he deserves that name, —Disdaining fortune, with his brandished steel, which smoked with bloody execution, like valor's minion, carved out his passage till he faced the slave; which ne'er shook hands, nor bade farewell to him. (Moore 12)

The word "slave" is mentioned in a panel that frames Evey's fear using extreme close up view to show her terrifying facial expression as her panicky teary eyes and edgy closed lips. (Moore 12) It also suggests how the totalitarian Norsefire government dominates the people and enslave them by fear.

$\mathrm{V}$, then, kidnaps Lewis Prothero, the voice of Fate, the radio broadcaster who misguides the civilian's perception. He dictates his fearful broadcasting; to spread fear to represses the citizens. Here, there is a direct reference to another postmodern technique, which is the involvement of different and more likely unreliable narrators who may manipulate the reader's perception and try to gain their compliance. $\mathrm{V}$ dresses him in a commander's uniform and imprisons him in a place presumably to be similar to larkhill camp, the concentration camp where $\mathrm{V}$ was held as an inmate and Prothero worked as a commander in the past. V guides Prothero through a tour in this camp to remind Prothero of his past deeds. Prothero attempts to deny his involvement with this camp. As they walk down, they come 
upon doors marked with Roman Numerals, Prothero realizes that his kidnapper was $\mathrm{V}$; his former prisoner. In a melodramatic moment, Prothero becomes confronted with his doll collection outfitted as prisoners. $\mathrm{V}$ fills an incinerator that most probably served as a crematory for slayed prisoners in the past, with Prothero's dolls and bursts them into flames and forces Prothero to witness. The dolls call out "ma-ma" and Prothero loses his mind. V sets him free with face painted like his dolls, he only says "ma-ma". (Moore 34)

After $\mathrm{V}$ has driven Prothero insane and thrown him out, he moves on to Bishop Lilliman who previously worked as a prison chaplain at Larkhill camp and is now the Bishop of Westminster church. Like the officials in the Norsefire government, V knows about Lilliman's pedophilic lust. V makes a deal with Evey to help him and facilitate his entry to the Bishop's accommodation by opening the window. Dressed like a little girl, Evey goes to meet the Bishop Lilliman makes a move on Evey who seems to be distressed with the bishop's advances. At first, Evey does not resist, she only tries to stall him by asking him to open the window as $\mathrm{V}$ wants, then asking him to read a piece of the Scripture. Lillimam takes her into his bedroom, and forces himself on her and tries to strip her. In spite of the fear she is experiencing, Evey resists; she hits his face with a lamp and runs away. As Lilliman chases Evey, he confronts $\mathrm{V}$ who kills him by forcing him to intake cyanide. Here, another postmodern technique is utilized, which is 
deconstruction, as $\mathrm{V}$, the hero, commits a murder, which deconstructs the traditional norm that stresses on the idealism of heroes, who should be flawless.

After killing Bishop lilliman, V pays a visit to Delia Surridge, who used to work as the doctor who conducted medical experiments on the prisoners at Larkhill camp. Surprisingly, Dr. Surridge does not seem afraid of V. To the contrary, she appears solaced when she sees $V$ as she expects him to come back for her. Dr. Surridge talks to V to vindicate her former deeds. Here, a postmodern non-linear technique is utilized while recalling what has happened at Larkhill camp. She tries to defend herself, as it has not been her call; she has been obliged to do what she has been ordered to do. Yet, she regrets what she has done; she still cannot live without blaming herself for her deeds at the cam Influenced by Dr. Surridge's sense of remorse, V injected her by a deadly shot so she does not experience any pain.

After murdering Dr. Surridge, V goes to the Shadow Gallery, where Evey stays in and considers as home. V plays a magical trick for Evey then he blindfolds her and asks her to come along with him and to listen to him without interruption. Evey hears a replaying of her earlier conversations with $\mathrm{V}$ in which she offers to help him in his mission but later tells him she would never participate in any assassination again even for him. Feeling cold, fearful and chaotic, Evey takes the blindfold off, to find herself in the street. Evey asks V to take her back to the Shadow Gallery. V tells Evey that he is not her father, and that her 
father is dead. Evey is deeply traumatized that she tries to burst at $\mathrm{V}$. Yet, $\mathrm{V}$ is not there, there is only a scarecrow dressed as $\mathrm{V}$ with a tape recorder. $\mathrm{V}$ has deserted Evey in the street.

After deserting Evey, V comes into the NTV broadcasting unit, while the on-duty guards are following either a show or news broadcast. The conversation from the show and news broadcast confusingly narrates the scene. $\mathrm{V}$ attacks the guards and breaks into the broadcasting room. He has trapped himself with explosives around his chest and threatened to blow himself up. V coerces Dascombe, the head of Mouth, the propaganda unit, to broadcast the video he has taped. V sits at the desk and demands the citizen's attention. V says, "Good evening, London. I thought it time we had a little talk. Are you sitting comfortably? Then I will begin." (Moore 112)

After V has walked out on Evey, She begins to live with Gordon who invites her to accompany him and he will take care of her in return. Unfortunately, afterwards, Gordon gets stabbed to death by a sword behind the front door of his home by gangsters, one of them called Harper. Evey knows the two men who murdered Gordon, she sits on the stairs, she seems traumatized that she recalls all the fearful events in her life that previously she could not react to and has caused her lonesomeness. Evey feels shield-less again, she recalls her mother's death, her father's abduction, V's desertion, and ends up with standing over Gordon's dead 
body. Out of despair, for the first time, Evey tries to react fiercely to achieve her own vendetta; she takes Gordon's gun to shoot the two gangsters who have murdered Gordon. Unexpectedly, someone grabs her from behind and knocks her out.

After being knocked out, Evey wakes in a gloomy cell with a rat and the Norsefire's slogan poster fearing that she will be executed. Two guards take her to what seems to be an interrogation room. The interrogator shows her evidence of her attempted prostitution and charges her with the attempted murder of Creedy. Then the guard blindfolds her and shaves her hair off. Then, she gets examined by an unidentified woman, and taken to the dark cell where there is a rat. In the cell, Evey finds a piece of toilet paper, documenting the prison experience of a woman called Valerie. Evey is taken again to the interrogation room where the guard pushes her and restrains her to a chair, and then he starts torturing her by shoving her face into water repeatedly while demanding information.

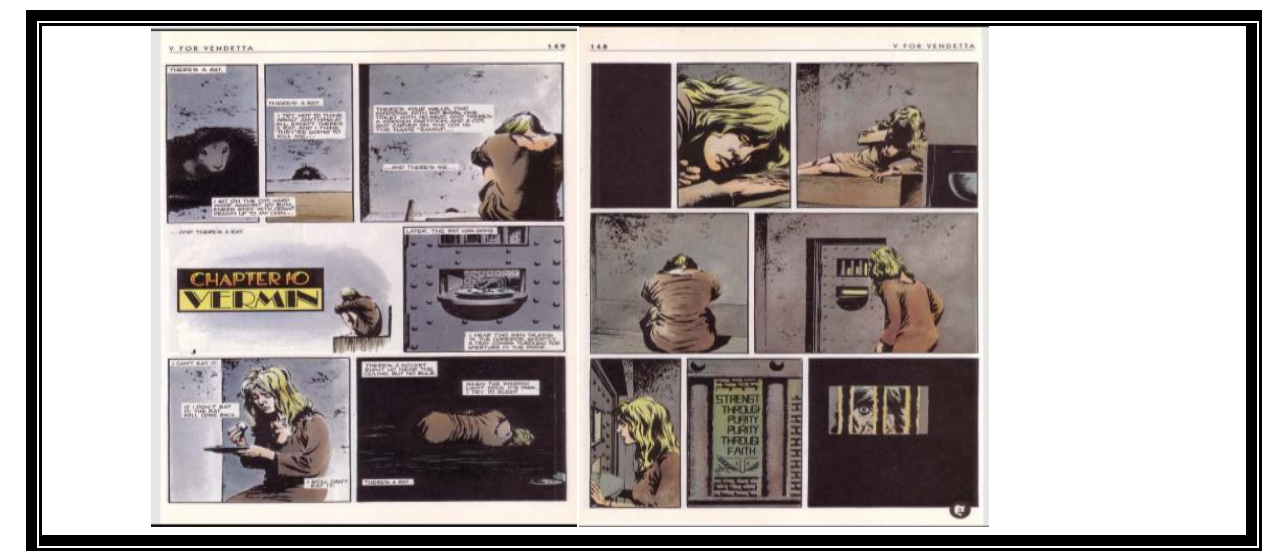



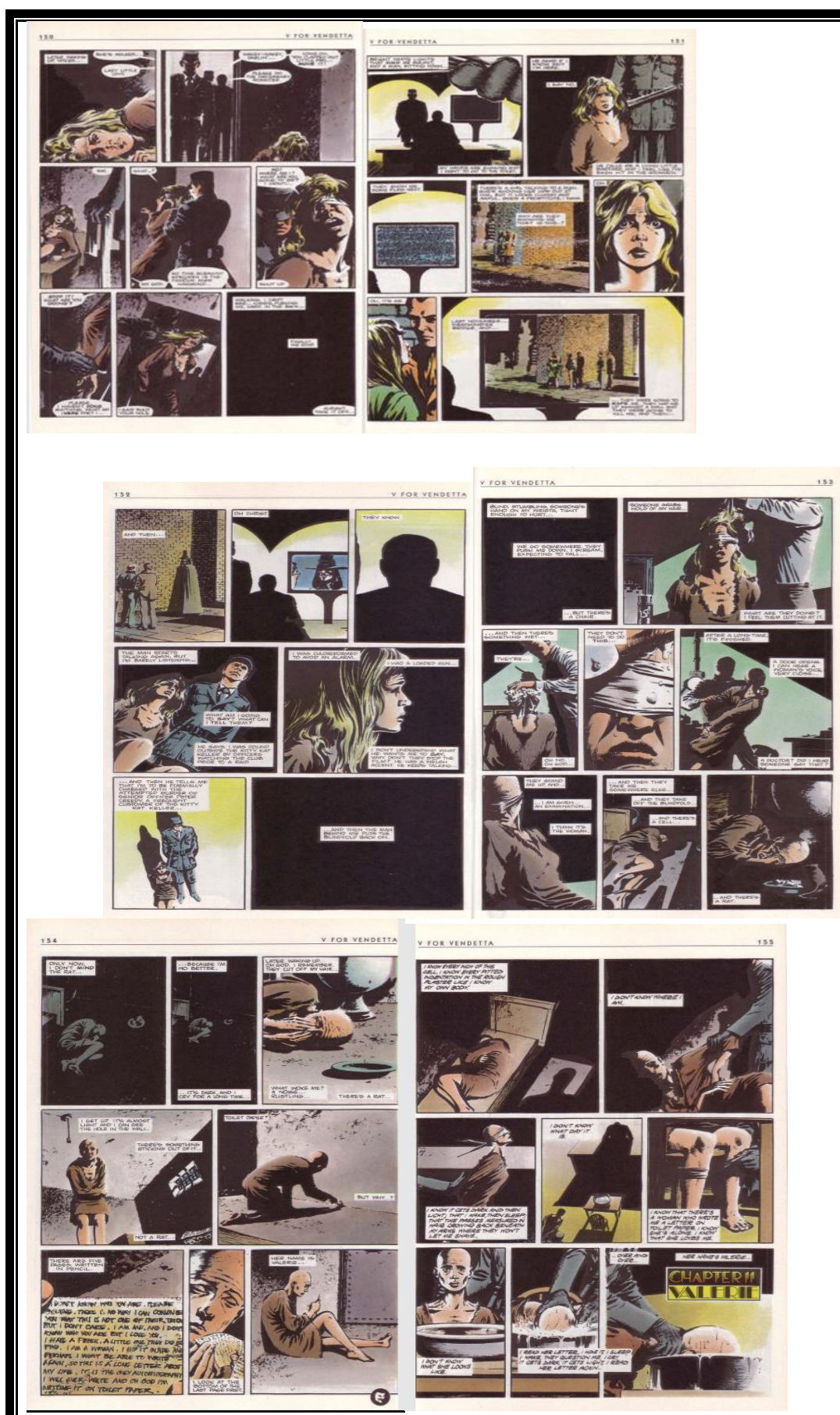
(Fig. (2) - Moore 148-55)

Here, the choice of moment for this scene is designed for immersing the readers within the prison walls alongside Evey to help better understand how she is feeling. Action to action transition is what is mostly used throughout the panels. As the readers get to see Evey waking up, clearly disoriented, the slowing down of the pace by nearly displaying moment to track every action helps to build up an immense sense of fear and powerlessness. Within the panel showing the Norsefire's slogan "Strength Through Purity, Purity Through Faith", the readers might get to believe that Evey is captured by the Norsefire government. (Moore 148) Thus, one of Evey's worst fears is confirmed, for she has been arrested by the fascist group who before caused the disappearance of her father. The transition fleetingly changes to moment to moment, as a rat is shown within the three panels; it appears as if the rat has become an object of which Evey focuses on as she realizes that "they're going to kill me". (Moore 149) Then, the transition switches back to action to action to display Evey's reaction. The chosen moments show how quickly Evey has been spiritually defeated, as she no longer eats, and does nothing except lying on the bed. Then the transition changes to subject to subject as prison guards invade the room and escort her away, more information are revealed about why she is in there. The readers switch between Evey, and the guards whose faces cannot be seen. 
Scene to scene transition is utilized to jump from TV screen and Evey's face in the interrogation room to the earlier scene where Evey has been caught while trying to work as a prostitute, then again to the earlier scene where $\mathrm{V}$ has appeared and confronted the fingermen, then back to the TV screen in the interrogation room. Back to subject to subject, the readers quickly realize why Evey is imprisoned, her attempt to kill Gordon's killers has been perceived incorrectly, as she is "formally charged with the attempted murder of senior officer Peter Creedy". (Moore 152) An allegation known to be false, however is not something extreme for the Norsefire government. The readers can follow Evey as she is tortured in prison, as her hair is shaved and she is subjected to a forced medical examination. Then back again to action to action transition, as Evey sits on the floor, cries in desperation, she comes to a conclusion that she is similar to the rat or even worse. The horror she has been through so far has apparently shocked her to her very core, causing her to lose her sense of humanity. Evey hears a rustling sound however, and it takes her mind off the rat, what she finds is a toilet paper that documents a previous prisoner's life, called Valerie. Once more the transition changes back to subject to subject to display the further torture that Evey is subjected to as the guards restrain her to a chair, and shoves her face into water repeatedly while demanding information.

As for the choice of frame, the choice of camera angles differs from high, low and eye-level angle. High angle is 
used to show Evey restrained to a chair in a dull place, then within her cell, as she is lying down helplessly in a fetus position, then in the panel displaying the interrogation room while a bucket of water is prepared to shove Evey's face into it. This just shows the powerlessness of Evey as compared to the powerfulness of the Norsefire government. It indicates how far Evey is broken, and how much she fears for her life now that she is imprisoned by the government that she knows to be merciless.

The use of low angle further demonstrates Evey's deterioration; as she gets pushed by the violent guards, then as she stands up to see where the rustling noise comes from. The readers can observe how powerless she is and how previous to finding the letter- she is utterly terrified of what will happen to her. Eye-level is the angle that is relied on for the most part, as the fairly neutral angle helps us to focus completely on Evey's suffering, and with the help of the appropriate medium distance, the readers learn more about her current situation. Extreme close-up and close-up view serve nearly a similar point, to highlight Evey's feelings. The readers see Evey extremely terrified as she sees the Norsefire's slogan, and it is as if she has aged 50 years, whenever the distance closes in, Evey's fear on her face becomes clearer. Closing in on Evey's torture and restraining scenes as well help to emphasize the magnitude of the monstrosity that prisoners face even without being convicted, for the Norsefire government is willing to torture any suspect. The use of long view as Evey watches the surveillance video of the night she met $\mathrm{V}$ makes fearful 
memories rise to the surface as Evey remembers that "they were going to rape me" (Moore 151), however for a second there Evey didn't recognize herself. As the view changes to a close-up and Evey's face is clearly displayed, she remembers, and this moment of forgetfulness shows how disconnected Evey has become from her past self that existed a year ago.

Moving on to the choice of image, the illustration of Evey in her imprisonment reflects her emotions and the ongoing terror. One of her visually distinctive traits is her shiny golden hair, as it gets shaved off, her facial expressions showcase her fear, as the innocence she once clung to is now falling on the ground as it is getting chopped off. Evey's facial expressions throughout these panels display how far being imprisoned is terrifying her, for not only she looks like she has aged tremendously, she displays feelings of fear, despair, agony and defeat. The use of a blindfold as she is being transferred between her cell and the interrogation room highlights her fear, as she loses her sense of surroundings whilst being tossed around roughly by the guards. Her skewed body language shows how vulnerable she has become, with her downwards head, her rolled shoulders, her hunched back, and the way her arms are crossed over her chest and Knees in a self-hugging pose. Within the time of her imprisonment, Evey's posture is imbalanced, which reflects how defeated she feels, now that one of her main fears has been confirmed, she is going to 
die, it has only become a matter of how soon will her tormentors get tired of her and eventually kill her.

In comparison to Evey whose facial expressions are clearly displayed, those of her fearful captors are hidden in the dark, only their body postures and hand gestures are displayed. Presenting the captors as anonymous figures or shadows is achieved to deprive them of their humanity. Their hands are only displayed to present them as tools in the hands of the Norsefire government to carry out evil deeds. The captors stand or sit straight in their formal uniforms adopting hostile attitude, their hands are displayed either while holding firmly the blindfolds or restraining Evey's hands and legs, or holding iron sticks, or shaving Evey's hair or roughly pushing and pulling Evey or sinking her head in the bucket of water. This juxtaposition further highlights Evey's deterioration and her fear.

Concerning the choice of words, they are displayed in an intersecting manner. Aside from a harsh exchange between her captors and herself, Evey is the narrator in these panels, as she narrates her feelings as a reaction to her imprisonment and torture. It is clear from Evey's words how quickly she feels humiliated that she lost her sense of humanity as she dehumanizes herself whilst deeming herself as no different to a rat. Evey says, "Only now, I don't mind the rat...because I'm no better." (Moore 154) The scenes of her rough torture alongside Evey's words “they don't need to do this", reflects how fearful the Norsefire government is. (Moore 154) The captors behave mercilessly not because 
they need to, but because they want to. They want to spread fear to achieve sustainability to the Norsefire government. As Evey reads Valerie's letter however, it is clear how she is becoming detached to the tragic turn her life has taken. Valerie's words that she loves Evey gives her something to hold on to in the midst of her despair. The letter becomes Evey's fixation, as Valerie's word that she "loves" Evey gives her the strength to endure. (Moore 155)

After being severely tortured, Evey's captors tell her that they will execute her if she does not confess that $\mathrm{V}$ has brainwashed and sexually abused her to make her help him. Yet, Evey steadily refuses. Shortly after, Evey discovers that $\mathrm{V}$ is the one who has tortured her. All that $\mathrm{V}$ wants is to set Evey free of her fear. Here, again the deconstruction technique is utilized, as the torture turns out to be $\mathrm{V}$, the hero, which deconstructs the traditional norm that stresses on the thoroughness of heroes. $\mathrm{V}$ assists Evey to gather herself. After getting along with Evey, V continues his mission and donates bombs to Jordon tower, the old post office tower as well as the Eye and Ear's bureaus, killing Etheridge, which causes the malfunctioning of those both surveillance and speaking broadcasting systems. $\mathrm{V}$ then broadcasts his news to the people of London. He tells the people that for three days, they will have the privacy to do what they want, saying "And 'do what thou wilt' shall be the whole of the law." (Moore 187) 
The leader, confused about the malfunctioning of the surveillance systems, and desperate to contain the situation, orders Creedy, the Finger, to spread further fingermen in the streets, cancel police leave, and shoot all looters. However, the people of London are getting increasingly out of hand. Fingermen march in the streets as a show of force to deter the progress of the disturbance. Yet, the minute they walk away after passing by a grocery store, it gets broken into. Consequently, assumingly for looting, the fingermen shoot a woman publicly. People who are used only to express their fear and never dare to express their anger, seem to be reacting against this incident. $\mathrm{V}$ tells Evey that the Norsefire government is not used to people speaking up, as its sustainability depends on the silence of the people. V explains, "It does not do to rely too much on silent majorities, Evey, for silence is a fragile thing... One loud noise, and it is gone."(Moore 193) V adds, "Noise is relative to the silence preceding it. The more absolute the Hush, the more shocking the thunderclap Our masters have not heard the people's voice for generations, Evey....and it is much, much louder than they care to remember." (Moore 194)

Because of the leader's aggravating orders, the people of London get progressively more out of hand that they express angriness towards the practices of the fingermen. It appears that the Leader does not seem as fearful as he has used to be, he seems as if he is ironically sympathizing with himself. Irony is a bedrock in postmodernism and a significant technique in the postmodernist narrative that depends on the readers' engagement and their 95 
comprehension of what they read, see or even feel. In an attempt to contain the situation, the Leader shows up in a highly secured parade in the street. In an attempt to restore fear in the people of London, he surrounds himself with armed fingermen to re-impose his authority and have the citizens of London remember the consequences they shall suffer if they dissent against him. Yet, it is a risky idea, as it can cause more disturbances. The Leader waves at the citizen of London, gloomily and timidly. He says, "But why can't I feel anything for them?" (Moore 232) In the crowds around his car, the readers can see the fingermen ordering people to "wave harder". (Moore 234)

Rosemary, the widow of Derek Almond, the ex-head of the Finger, who has been killed by V, is angry with the Norsefire government that her deceased husband has served for very long time. She thinks that Derek has died for the Leader's sake. After his death, she has suffered from negligence and poverty and has had to work as a stripper to support herself financially. She decides to revenge from the leader whom she holds responsible for her misery. She moves through the crowd at the parade until she comes closer to the Leader, pulls her gun, and fires at him in the face. 

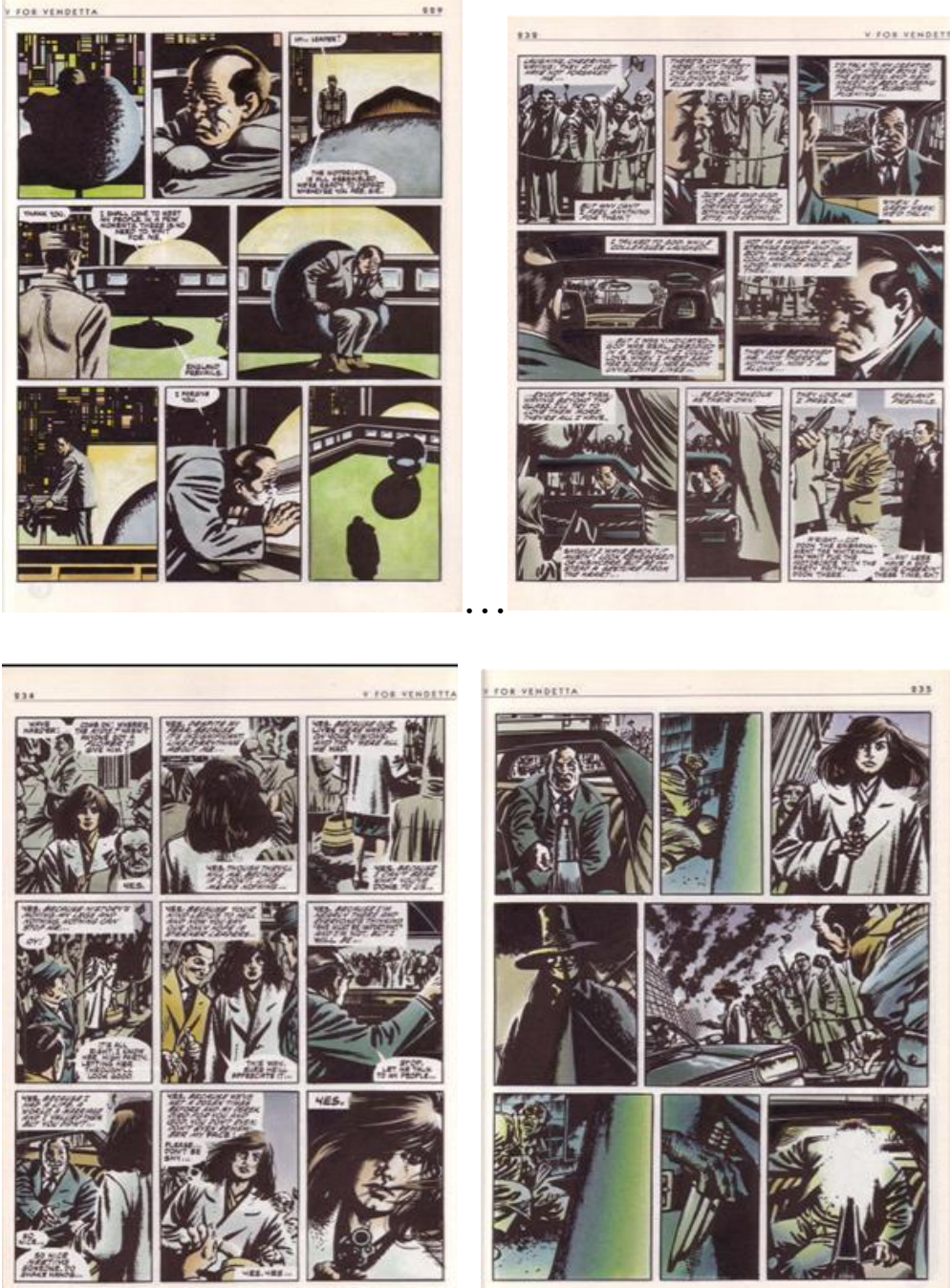

(Fig. (3) - Moore 148-55)

In these panels, the choice of moment changes from action to action to subject to subject. The action to action transition focuses on the defeated Susan, as V's hacking of Susan's computer "Fate" has left him experiencing fear and uncertainty. The transition changes to subject to subject as 
Susan gets out in an attempt to remind the people that the fearful Leader is still there to restore order and that the people should not go out of line. As the panels switch between the people to Susan, the readers can see that Susan has little to zero care for the people, being obsessed over his computer "Fate" has left him disconnected from the people. Even the people, they are not in the street to greet him of their own free will, as the readers can see them being held at gunpoint and ordered to "wave harder" by the fingermen; and the only one who is there of her own free will, is there to kill him. (Moore 234) The transition between Rose and Susan amplifies suspicions, as the readers sit on the edge of their seats anticipating Rose's next move. Rose is allowed to get close to Susan because she has used to be of the "high party" so there should be no fear of her to get close to Susan in a ruse to display the Leader's fake closeness to the people. (Moore 234) Both their stories reach their climax; Rose shoots Susan in the face just as Susan is attempting to build a connection that is not with a computer screen.

As for the choice of frame, the camera angle is kept steady throughout the scene, with exception to one single panel where high angle is used. The panel shows a different Adam Susan, a one who is not powerful and fearless anymore, instead he has been defeated by V's controlling of "Fate" and the angle amplifies how far he has fallen. The eye-level angle that is used in the rest of the panels provides a neutral perspective from which the readers get to observe V's chaos while unfolding, as Susan ends up being killed by 
Rosemary without ever learning the reason he has been killed for, just like all the other people who have been executed by the Norsefire government. Unlike the angles, an array of views are utilized to tell the scene, from long view to extreme close-up. Close to extreme close-up views are used first to display the fearsome Susan in a fearful state, then to show how the formerly timid and submissive Rosemary takes control of her life, as she plans to kill the man responsible for her suffering and many others, the first and apparently the last act of her life. They draw all the attention to the character's faces to amplify the emotions that they are experiencing.

The use of long view accentuates Susan's smallness and his powerlessness when facing V's chaos. Here, a postmodern tendency towards scattering chaos in the closure as it happens in the opening is utilized. Medium view provides an objective perspective to observe the chaos, as the readers can see the people cheering for Susan, but they know it to be fake. Then they can see Rose while shooting Susan in revenge of all the atrocities he has committed. The view shows the full picture of the Norsefire government's deception and the usage of fear to control the people. Regarding centering, Susan's distressed childlike posture is centered to accentuate the buried fragility of the cruel leader that is masked by the superficial callousness. Also, centering Rosemary in about 8 panels sheds light on the daring deed she is planning to do. In addition, the gun, which she used to shoot Susan's head, is centered to 
highlight its importance. This reveals that London after the leader's murder will sure differ from London before his.

Moving on to the choice of image, Facial expressions and body language are utilized to showcase the juxtaposition between Rosemary's character and Adam Susan's. It is illustrated, "In comics, where images are at least half the language, pictures can form valid narrative as easily and functionally as words - and, at times, without them". (Lewis 76-7) Adam Susan is shown afraid and deeply disturbed, a result of learning that his beloved "Fate" has been infiltrated by V. It is quite ironic for the man who has instilled fear in the hearts of many to experience fear firsthand, his emotions in these panels range from despair and defeat to unadulterated fear when he sees the gun Rosemary has pointed at him. His body language too shows a defeated man, as he is shown slumped and skewed, hugging his knees like a panicked child, covering his face with his hand out of despair, or wavering in his car as if he is unsure of himself. This is shown as well in his uncertainty when he faces the people; he says, "Should I wave back? It mustn't look rehearsed or insincere." (Moore 232) He is unsure of even the smallest of things, having been obsessing over "Fate" for far too long, he has lost the ability to connect and relate to other people, and this cultivates a feeling of insecurity inside him.

On the other hand, there is Rose with her unwavering facial expression, displaying complete and utter 
determination to complete the task she has set out to, even if she knows that she will be killed after as she says, "Yes, though they'll kill me." (Moore 234) Her body language displays elevation. She has reached the climax of her arc, from a submissive woman being forced to prostituting herself for sustenance, to the woman who is giving her life in sacrifice to murder the man who has caused misery for a whole lot of people. This is clearly demonstrated through the grit of her eyes and firmness of her hand while holding the gun to shot the leader. The tables are turned in these panels, for the fearsome is now fearful and the fearful is now fearsome, as Susan sits like a cowering child, while Rosemary stands to end Susan's dictatorial and fascist reign.

Regarding the choice of words, they are displayed in an intersecting manner, using words to provide insight into the mind of the now fearful Susan and the fearless Rosemary. It is illustrated, "The juxtaposition of words and pictures highlights a common element of pretense." (Di Liddo 114) As V's words have foreshadowed previously, "For him, I've cultivated a most special rose". (Moore 221) Even without words, the readers can tell that Rosemary is there to avenge herself and murder Susan. Yet, the innermonologues of both characters reflect their mental state, and combined with images to masterfully tell the climax of both characters. The readers can also see Norsefire government's familiar fear instilling antics, as they can see fingermen holding the people at the parade at gunpoint, while reading the fingermen's order to "Wave Harder". (Moore 234) They can see Rose being trusted to get near the Chancellor, while 
expecting the outcome from her inner-monologue for she will no longer "crouch like an animal and offer my hindquarters in submission to the world." (Moore 205)

Here, the choice of flow is unclear and it takes a while for the readers to process the images, follow the incidents and escape the baffling. The unclear flow symbolizes the disarray and the chaos that $\mathrm{V}$ has caused by hacking the leader's computer. According to the researcher, the flow is somehow confusing; some may justify the inconsistent of the flow as it is utilized to reflect the lack of control that the leader of the Norsefire government is now being suffering from. Susan used to be the most fearful figure in the government, yet, now, he is not sure about anything, and he appears in a total miss. Thus, the dismay he feels from the people who have long since lived in fear confuses him badly.

The head of the snake is cut off as Rose lethally shots Adam Susan, the leader of the Norsefir government. Consequently, most of its officials end up either absconded or killed. Dominic and Finch wait while watching the rioters who follow the symbol of V. Finch argues with Dominic that $\mathrm{V}$ has "become some sort of all-purpose symbol to them, hasn't he? People need symbols, Dominic. He understood that. We've forgotten it". (Moore 252) Accordingly, Finch decides to pull himself out of London before it flare $\mathrm{u}$ Finch concedes that he has tried to solace himself for losing all his family in the war by obeying 
orders, but he was wrong, as it has never eased his pain. Finch declares that he will only follow his own orders from now on. Finch says, "I'm following my own orders now. And getting out before everything blows. Perhaps you should, too. Goodbye, Dominic. Take care, lad." (Moore 252) Conrad murders Harper, but gets lethally wounded. Mrs. Heyer sets up a camera so Conrad can watch himself die, instead of getting him help, and madly accuses him of damaging her plans. All of the Norsefire officials receive ironic punishments. Perhaps the most ironic is Conrad's. Here, irony, again, is utilized as there is a postmodern tendency that once the readers detect the ironic perception proposed in the narrative, they begin to deduce ironical interpretations that vary from one reader to another. Having spent his entire life watching other people, Conrad is forced to die watching himself bleed out.

By the end of $V$ for Vendetta, finally, fear is conquered, as the rebellion of the people of London against the Norsefire government continues in spite of the rumors of V's death. Evey overcomes her fear and decides to become the new V. Upon the original V's request, she prepares a Viking funeral as she puts him in a glass casket in the train that is trapped with explosives to blow up Downing Street. Evey promises $\mathrm{V}$ to help the people defeat their fear of the Norsefire government, she says, "The age of killers is no more. They have no place within our better world." (Moore 260) Then, she grabs Dominic, a senior official now that all other officials have gone missing or dead, and introduces him to her home, the Shadow Gallery, to prepare another V. 
Here, another postmodern technique is adopted, which is historiographic metafiction. The mask of $\mathrm{V}$, muses the assets of rebellion against repression, as it creates a modern version of Guy Fawkes figure who repelled against the increasing oppression of the Roman Catholics in England during the reign of James I. (Di Liddo 174)

\section{Conclusion:}

This Paper examines $V$ for Vendetta as a remarkable postmodern piece of work that has paved the way for comics to be regarded as a sophisticated literary genre. It, also, inspects the theme of fear and how it is manifested through both texts and images by employing McCloud's five choices: choice of moment, choice of frame, choice of image, choice of word, and choice of flow. Each choice has been investigated to show how $V$ for Vendetta tactically make use of each choice to demonstrate the theme of fear throughout its texts and images. It is evidenced that fear is one of the pillar of V for Vendetta as it is considered the most prevailing feeling and motivation. 


\section{Work Cited}

Chute, Hillary. "Comics as Literature? Reading Graphic Narrative". Modern Language Association, Vol. 123, No. 2, 452-465, Mar. 2008, accessed 12/12/2017, http://www.jstor.org/stable/25501865

Di Liddo, Annalisa. Alan Moore: Comics As Performance, Fiction As Scalpel, University Press of Mississippi, 2009, Print.

Hatfield, Charles. Alternative comics: An Emerging Literature. Jackson, MS: University of Mississippi Press, 2005, Print.

------- "Foreword, Comics Studies: The Antidiscipline", in The Secret Origins of Comics Studies, Matthew Smith and Randy Duncan (Eds.), Routledge, IXVII, 2017, Print.

Lent, John A. "The Winding, Pot-Holed Road of Comic Art Scholarship", Studies in Comics Vol. 1: No.1, 7-33, 2010, accessed 13/11/2018, Doi: 10.1386/Stic.1.1.7/1 .Web

Lewis, A. David. "The shape of comic book reading", Studies in Comics Vol.1, No. 1, 71-81, 2010. accessed 8/8/2017, doi: 10.1386/stic.1.1.71/1

McCafferty, Kaitlyn. "The Power of Non-Sequitur Transitions", Art Ducko, February 2017, accessed 13/2/2019, 
https://artduckomagazine.wordpress.com/2017/02/08/thepower-of-non-sequitur-transitions-by-kaitlyn-mccafferty/

McCloud, Scott. Making Comics: Storytelling Secrets of Comic, Manga and Graphic Novels. Harper, 2006, Print.

Meskin, Aaron." Comics as Literature?" , Oxford University Press: British Journal of Aesthetics Vol. 49, No. 3, 219 - 23, 9July 2009. accessed 10/3/2018, https://10.2478/abcsj-2018-0008

Moore, Alan, et al. V for Vendetta. DC Comics, 1989, Print.

Wandtke, Terrence R. The Meaning of Superhero Comic Books, Jefferson: McFarland \& Company Publishers, 2012, Print.

Wardrip-Fruin, Noah and Nick Montfort. Eds.The New Media Reader, Vol. 1, MIT Press, 2003, Print.

Wolk, Douglas. Reading Comics: How Graphic Novels Work and What They Mean. Cambridge, 1st ed. MA: Da Capo, 2007. Print. 